Mbiba, B. () 'Idioms of accumulation: corporate accumulation by dispossession in urban Zimbabwe', International Journal of Urban and Regional Research

DOI:

This document is the authors' Accepted Manuscript.

License: https://creativecommons.org/licenses/by-nc-nd/4.0

Available from RADAR: https://radar.brookes.ac.uk/radar/items/51fa4c94-6d78-4785-a9d4-618df57e78c8/1/

Copyright $(\subseteq$ and Moral Rights are retained by the author(s) and/ or other copyright owners unless otherwise waved in a license stated or linked to above. A copy can be downloaded for personal non-commercial research or study, without prior permission or charge. This item cannot be reproduced or quoted extensively from without first obtaining permission in writing from the copyright holder(s). The content must not be changed in any way or sold commercially in any format or medium without the formal permission of the copyright holders. 


\title{
IDIOMS OF ACCUMULATION: CORPORATE ACCUMMULATION BY DISPOSSEION IN URBAN ZIMBABWE
}

\begin{abstract}
David Harvey's accumulation by dispossession has inspired a wide range of studies in different places. But it has hardly registered in the area of urban land grabbing in Africa and the role of local capital in these processes. Using archival data, field observations and insights from key informant interviews in Harare, this paper examines how the 1990s neo-liberalism and post 1999 Zimbabwe crisis created new opportunities for accumulation of wealth through irregular and fraudulent transfer of public urban land into private hands including those of reputable corporate institutions. It speaks to the literature on contemporary land grabbing and raises questions and new insights for comparative understanding of the transformative role and nature of the state, postcolonial African cities, anti-capitalist struggles, the status and meaning of planning in different settings.
\end{abstract}

\section{Introduction: political and institutional settings}

McGregor (2013: 784) correctly observed that the period of Zimbabwe's Inclusive Government (IG) from 2009 to 2013 in which the ruling 'revolutionary' liberation nationalist party ZANU (PF) shared power with the neo-liberal opposition Movement for Democratic Party (MDC) parties 'opened up limited new political space' to contest ZANU (PF) hegemony, to expose corruption and partisan practices especially within urban councils. Since 2000, like most ruling parties in Africa, ZANU (PF) has consistently lost the urban vote to the MDCs who now control all major councils (Mbiba and Ndubiwa, 2009: 90; McGregor 2013: 784). However, ZANU $(\mathrm{PF})$ 's control of the state and central government enabled it to sustain a vice grip on urban local authorities through inter alia, the machinations of Dr Ignatius Chombo, then Minister of Local Government Rural and Urban Development (McGregor, 2013; NewZimbabwe.com, 2016). As anticipated by Bond and Manyanya (2002: 175), urban governance has become the most durable site of political conflict and contestation. It is within this context of a polarised political environment and economic crisis that a Special Committee of the City of Harare chaired by Councillor Warship Dumba produced a $23^{\text {rd }}$ March 2010 dated "Special Report on City of Harare Land Sales, Leases and Exchanges From The Period October 2004 to December 2009". We shall call this the Dumba Report.

The Dumba Report provided archival data exposing what the media characterised as a massive land scandal in which Minister Chombo and business mogul Phillip Chiyangwa were allegedly leading among the wealthy Zimbabweans, shelf and briefcase businesses and corporates that benefited from corrupt public land transactions. The report called for a countrywide investigation given the high probability that similar practices were taking place in other urban local authorities large and small. Indeed the likelihood of this is confirmed by the recent grab of Meikles Park in the central business district (CBD) of Mutare City (The Standard, 2014). A portion of the Meikles Park public open space (POS) had been used by rent paying traders for years. But in 2011 it was targeted for 'acquisition' by Chinese investors who failed courtesy of a vigilant MDC mayor and council (NewZimbabwe.com, 2014). However, Minister Chombo appears to have used his ministerial 'eminent domain' powers in land acquisition to transfer the public land from council to government ownership and then had it handed over to Esau Mupfumi, a local ZANU (PF) heavyweight politician and business mogul. Media reports claimed that Mupfumi intended to construct a hotel on the site (New Zimbabwe, 2014).

Surprisingly, despite the media coverage of such urban public land grabs corroborating revelations in the Duma Report, scholars have paid no attention to it. The Dumba Report's call 
to investigate potential plunder in other cities has gone unheeded. Yet, the import of its contents for urban planning, governance and broader social science scholarship on land and African development seems far reaching. Few topics in Southern Africa and Zimbabwe in particular have been more widely discussed than land (ICG, 2004). Yet, this research and political concern with land persists with a rural orientation and dispossession of White commercial farmers (see for example Hanlon et al. 2013; Scoones, et al. 2010). Where the urban dimension is considered, this has been tentative and targeting low income housing, peri-urban transformations and land struggles and ZANU (PF) patronage networks (Marongwe, 2002; Sadomba, 2011, Marongwe et al. 2011; McGregor, 2013). Meanwhile, the recent burgeoning global debate on land grabbing or dispossession has raged on with little reference to the Zimbabwe land question generally let alone the Zimbabwe urban land question ${ }^{1}$; hence the paper bridges gaps in the rural-urban disciplines.

This paper partly fills gaps in the burgeoning literature on 'land grabbing'; a catch phrase referring to the explosion of large scale transnational commercial land transactions and land speculation in Africa, Asia and Latin America triggered by the 2007 global food crisis (Fairhead et al. 2012; Baglioni et al. 2013; Borras and Franco 2013; Oya, 2013; Hall, 2013; Edelman et al. 2013). Although this literature has attempted to correct its earlier lack of historical perspective, the key focus has been on the role of global capital, the sensational, spectacular and the large scale (Oya, 2013). This has left under the radar national, 'small scale' or micro-level yet similar ${ }^{2}$ and equally important land transformations especially in urban and peri-urban Africa (Becker, 2013; 113; Oya, 2013: 1532); thus land grabbing should not be about size but essence.

Gillespie (2013)'s insightful literature review shows that urban and geographical studies have sought to understand urban 'land grabbing' or 'dispossession' through concepts of gentrification, regeneration, urban revanchism (Smith, 1996), enclosure, rights to the city (Harvey, 2012), evictions, and increasingly use of Marxist accumulation by dispossession theories. All are potentially useful for understanding abuse of planning and illegal urban land processes in a neoliberal world and to go beyond the labels of graft, corruption and institutional decay (Southall, 2005; Goodfellow, 2013) used in the context of urban Africa. However, there is little dialogue among various strands of this literature. Concepts like 'gentrification' and 'urban revanchism' (Smith, 1996) used in the Global North have not been deployed to understand large scale dispossessions and urban evictions such as Zimbabwe's infamous 'Murambatsvina' or clean out the filth (UN-HABITAT, 2005; Kamete, 2006, Sadomba, 2011).

Further, as argued by Hodkinson (2012) and Gillespie (2013), historical and geographically specific urban research (for this paper African) is sorely needed on the dynamics of accumulation by dispossession. Addressing these concerns, this paper brings to the global debate Zimbabwe's less familiar urban public 'land grabbing' dynamics that take place in the heart of the city and prime lands in the high income high value low density areas that to date remain only a media rather than scholarly focus. In these spaces, how do the patronage

\footnotetext{
${ }^{1}$ Recent special journal issues devoted to this topic include Journal of Peasant studies (March 2012 and May 2012); Journal of Development Studies (December 2012); Development and Change (March 2013); Globalisation (March 2013) and single articles in journals such as Geoforum, Journal of Agrarian Change; scholarship initiatives at www.futureagricultures.og/land-grab.html and www.iss.nl/ldpi,a and The World Bank (2011).

2 See also page 2 of Report of LANDAc International Conference, 8 -10 July 2015. http://www.landgovernance.org/landac-2016-international-land-conference-30-june-1-july2016/
} 
dynamics work to enable accumulation of wealth and by who? Using the concept of accumulation by dispossession, how can theorisation of land processes and African development elsewhere be enriched by empirical analysis of elites' involvement in land 'grabbing' in these urban spaces? The questions are also important locally and continentally especially for leftist scholars (e.g. Moyo and Yeros, 2005, 2007; Mamdani, 2008), Zimbabwe's war veterans and supporters of its liberation movement regarding how these processes fit in with ideas of freedom and independence and their implication for Zimbabwe's terrain of contradictory development (Sylvester, 1991).

The paper draws on David Harvey's (2003, ) concept of accumulation by dispossession (AbD) to enable contingent yet comparative linkages with local as well as global contemporary and historical literature on land grabbing, urban governance, the post-colonial African city and state. Following a summary of the data collection methods, key aspects of AbD as understood and used in this paper are outlined. Elements of this conceptual apparatus include the issue of 'crises' within capitalism. Each phase or crisis of capitalism creates opportunities for destruction and accumulation for some while putting others into abject poverty. Hence the need to narrate the Zimbabwe crisis at the national and local government level and how this provides (ed) a context for new modes, 'regimes' or idioms (Cheater, 1984) of regulation and accumulation of wealth. However, the endemic disagreements on causes and solutions to the crisis will not be pursued here (see e.g. CDR, 2002; Crisis Coalition Zimbabwe 2003a, b; Scarnecchia et al. 2009, Compagnon, 2011; Godwin, 2011; Freeth, 2011 vs ICG, 2004; Mbiba, 2005; Moyo and Yeros, 2005, 2007, 2009; Mamdani, 2008; Sadomba, 2011).

The Zimbabwe crisis is divided into two broad phases; the neoliberal moment of the 1990s and the 'new millennium'. To illustrate how the first phase of the crisis was used as a context of $\mathrm{AbD}$, the paper draws on archival material from the 'embargoed' Thompson Report (GoZ, 1999) in which the then Executive Mayor of Harare set the template of how Zimbabwe's new elites (see Weiss, 1994) could use and abuse the local government system for wealth accumulation in urban land. The Dumba Report captures fraudulent land allocation in the second phase of the crisis. But it did not give prominence to corporate accumulation by dispossession cases such as those by the Commercial Bank of Zimbabwe (CBZ) highlighted here. Presented in two parts, these highlight how the bank (and others) used the crisis as an opportunity to accumulate wealth; in particular through privatising public urban land. The first case relates to the public open space (POS) land that was a People's Market on the eastern edges of the Harare CBD. The second case is that of a POS Nature Reserve in the Borrowdale low density high income area to the north of the CBD. Whereas the first case involved traders, the state and local authority, the second one, still awaiting Administrative Court judgement as at September 2014 involves the local authority, the state and pits CBZ against other corporate entities.

\section{On methods and data collection}

The neglect of urban public land in the study of politics, patronage and 'land grabbing' in Africa is puzzling. Even more puzzling is how Zimbabwean scholars have failed to collect and utilise abundant archival data from the bureaucracy. Zimbabwe inherited (from Rhodesia) and maintains one of the most comprehensive surveillance systems with records kept for almost every aspect of public and private life (Mbiba, 2010). This includes records on land use, land ownership and land values, births, deaths and national identity cards.

Thus the study made attempts to collect and analyse public archival data on land use change and ownership collected in terms of the Regional Town and Country Planning Act [Chapter 29: 12] (RTCP) and allied legislation. This involved institutional visits to the central government's Department of Physical Planning (DPP), The City of Harare (Departments of Finance, Urban 
Planning Services (UPS), Mayor and Town Clerk's Offices) and to a minor extent, the Administrative Court and the Deeds Registry. The visits sought archival data on specific public land parcels known or suspected to have been the subject of fraudulent allocations. Interviews were held with senior officers in these institutions and site photos were taken. Spatial planners were asked for access to archival data on specific sites, to explain the history of and arguments relating to change of use or reservation for each site and to identify and describe the role of different actors in each development.

Where disputes are not resolved in the planning system, aggrieved parties can approach the Administrative Court. The court record or decision is usually a very comprehensive synthesis of key issues and captured in duplicate form. Copies of the record are also filed at central government and the local authority. Similarly, in cases where change of reservation or "call in powers' of the minister are used, the paper trail is filed both at the local authority and at the DPP. Legal experts and planning consultants representing the different parties also have copies of correspondence and case details. There is a legal requirement that change of ownership and planning application notices be advertised in national newspapers. Thus there is a rich tapestry of archival data for triangulating each case. Crucially, the study interviewed directors responsible for properties ${ }^{3}$, land and investment at CBZ to verify and confirm information on the bank's acquisition of 'The People's Market' and 'Borrowdale Nature Reserve' plots. The councillor for Borrowdale was also interviewed ${ }^{4}$.

Fraudulent land allocations can be a sensitive topic to study. Except for the Administrative/High Court files, access to the archival data was not problematic. These archives are public records (all hard copy) available to urban planners and the public during the course of planning decision making. The title 'urban history and land use change' used to gain access for this study could be construed as 'deception' or disguise. Yet it was practically necessary (Adams and Megaw, 1997) as it provided officials with plausible reasons to grant access. At the High Court, the gate keepers needed third party confirmation that the researcher was a planner and not a journalist while at Harare City Council one relevant archival file 'was not found'.

\section{Conceptual apparatus: accumulation by dispossession}

Despite criticisms and challenges (Hall, 2013: 1583), ambiguities and confusion (Levien, 2012: 936-937), Harvey's (2003) reconstruction of Marx's 'primitive accumulation'(PA) as 'accumulation by dispossession' (AbD) seems to be the most potent conceptual basis to understand contemporary processes of land dispossession in diverse places (Borras et al. 2012) and different forms of capitalism (Glassman, 2006; Rossi, 2012). Figure 1 sketches key elements that often lead to confusion in use of the concept but that should be considered as part of the conceptual apparatus employed in this paper.

Confusion and ambiguities arise from the different emphasis scholars give to different elements (Hall, 2013) in their conceptualisation of PA versus AbD and in interpretation of case studies. First is the question of purpose or function that PA or AbD plays in relation to capitalism. For Marx, accumulation of surplus value is made through capital and capital is made through surplus value. The labour process is central to these economic means of value creation. The purpose of PA is to create the conditions necessary for capitalism to emerge. In AbD (Harvey, 2003, 2006) the purpose is not just to create conditions for capitalism where these do not yet exist but to speed up and expand capitalist processes. Marx (1990: 874) termed the starting point, the point of departure for this capitalist mode of production, "primitive accumulation" whose means

\footnotetext{
${ }^{3}$ Interviews $21^{\text {st }}$ August 2014

4 Interview, $13^{\text {th }}$ August 2014
} 
were/are "conquest, enslavement, robbery, murder, in short force..." These means are still prevalent in the processes of contemporary accumulation although the role of different actors may differ depending on context. Thus after purpose, means are the second feature.

Harvey $(2003,2014)$ recognises that there is an interplay of both economic and extra-economic means (force, fraud etc.) economic means (debt, finance) and by subsumption in present day processes of dispossession taking place in advanced capitalist spaces as well as in 'primitive' or least advanced regions. Privatisation (a feature of PA), operates hand in glove with financialisation, helping to expand and speed up capitalism but at the same time creating and perpetuating a sense of crisis while appearing to offer answers to the same crises. Harvey (1985; 2014) has offered an eloquent elaboration on the contradictions inherent in capitalism and how these give rise to numerous crises. The nature of the crisis may vary from case to case, but its origins and links to capitalism are as important to understand as the manner in which the state and other actors respond. As will be illustrated in this paper, there is no singular crisis (Harvey, 2014) and no singular actor response.

Outcomes or effects are the third area of debate. For Marx, (see also Glassman, 2006: 610) the result or outcome of primitive accumulation is a polarisation of the commodity market into two classes (i) capitalists who own the means of production and (ii) workers or wage labourers who lose control of the means of production and who have nothing other than their labour power to sell. The polarisation can take other dimensions and in line with Becker (2013) the data in this paper shows that what seem to be small-scale land transformations have far reaching impacts in consolidating a super-wealthy local 'vigilante' capitalist elite (Moyo and Yeros, 2009). Most social scientists appear to recognise these $\mathrm{AbD}$ outcomes and understand $\mathrm{AbD}$ as "... ways in which neo-liberalisation has transformed the matrix of city spaces, entailing intensified differentiation, displacement of the poor and a significant degree of conflict and contestation" (Springer, 2013: 445). However, in this Zimbabwe case, while neo-liberalism was a trigger of 1990s accumulation by dispossession, the context of subsequent crises marginalised global neoliberal actors. For Moyo and Yeros (2009) global capital went on strike. Yet AbD (urban land grabbing) has expanded in recent years driven not by global capital but by national and local actors who seem critical of global neo-liberalism but continue to operate within its premises. Here may be a case of AbD outside of or without global neoliberalism but homegrown neo-liberalism.

The role of actors is key in the historical and contemporary conceptualisation of $\mathrm{AbD}$ particularly in how they deploy economic and extra-economic means (Glassman, 2006; Hall, 2013) or how they are affected by these means and react to them. In the neoliberal context, the state may privatise or delegate use of coercive powers (e.g. use of private security firms to deal with evictions). Crucially, the state's redistributive interventions may favour capitalist business interests over others, for example through the tax system (Fairhead et al. 2012) or in allocation of public land as presented in this paper. In each case study, we therefore have to inquire into the role of the state, the mechanisms deployed and whether and to what extent the outcomes benefit specific varieties of capitalists.

Hall's (2013) review shows that foreign acquisitions of large pieces of land (World Bank, 2011) is the dominant concern in agrarian studies dealing with land dispossession. Cases in this paper illustrate how national and local actors can be very dominant and how pieces of land that appear small-scale could have significant long term impacts on urban economies and national politics. We have to examine the balance between the economic and extra-economic means (Glassman, 2006); the global versus the national and local actors; the inside from the outside processes. How actors respond to different crises, the alliances forged, the outcomes in terms of 
accumulation and dispossession and the response (Hall, 2013) or lack of from those affected (Borras and Franco, 2013) are questions to which this paper will contribute. To arrive at these contributions, the context of crises in Zimbabwe needs to be sketched next.

\section{Zimbabwe crisis: neoliberal moment and mayoral-led plunder in the 1990s}

Bond and Manyanya (2002) seems to be the most exhaustive and balanced narrative not only of Zimbabwe's failed 1990s neoliberal policies but significantly the interlocking structural capitalist origins of the political economy crises, their contemporary metamorphosis and manifestations in socio-political upheaval, international relations impasse, jambanja (the post 1999 fast track land reform), food shortages, election violence, collapse of services especially water, sanitation and electricity and increased human rights violations at all levels of society. Their analysis underlines simultaneous interlinkages of global and local capitalist interests: it would be incorrect to single out one as more important than the other.

At independence in 1980, Zimbabwe inherited a highly protected, racially segregated import substitution driven European settler colonial capitalist socio-economy whose infrastructure was destroyed by a decade of civil war. Although then the second most advanced Sub-Sahara economy (after South Africa) it was shackled by odious debts, limited local markets, obsolete technology and production systems that reduced capacity for value creation and productivity in manufacturing. The new government embarked on redistributive policies (education, health, infrastructure) to cater for the marginalised majority Black Africans. But public debt and unemployment worsened. Manufacturing stagnated as capital flows shifted into speculative stock markets and real estate. The inherited contradictions of the settler economy persisted. At 1989, the depth of the country's capital markets was ahead of those for Chile, Korea, India, Singapore and Greece (World Bank, 1989: 23, 56). But White settlers and foreign institutions continued to control land and benefit most from the economic status quo. For instance, $97 \%$ of bank loans in 1989 went to white owned firms ${ }^{5}$. The indigenous Black Africans remained marginal to the economy.

Consequently, in a bid to address the worsening multiple socio-economic and political challenges, in 1990/91 government adopted a neoliberal export oriented IMF/World Bank driven Economic Structural Adjustment Programme (ESAP). This inter alia, prescribed financial deregulation, labour retrenchments, removal of subsidies and import barriers all of which accelerated deindustrialisation, rapid decline in living standards and political discontent. Concern for this paper is on Government responses to the crisis and their implications for cities. To support those who lost their jobs due to ESAP and to facilitate greater control and economic participation of the Black majority in a neoliberal environment government promoted 'affirmative action' and 'indigenisation' (GoZ, 1993; 1994; 2008).

For instance, Statutory Instrument (SI) 216 of 1994 (GoZ, 1994) relaxed development control regulations in urban local authorities to allow home based enterprises in residential areas. This way, Blacks who could not afford land in prime areas could start businesses and employ themselves with low start-up costs (ironically, most of these enterprises were destroyed by Murambatsvina in 2005). Government made it mandatory for large corporate construction firms to subcontract up to $15 \%$ of the contract value of their projects to indigenous contractors while government departments were to offer at least $10 \%$ of contracts to indigenous firms (GoZ, 1993). Post 1999, indigenisation was vigorously pursued inter alia as 'jambanja 'or third 'chimurenga' (revolution) - the fast track land reform or White commercial farm land grabs (depending on ideological orientation) (Scoones et al. 2010) as well as laws that require foreign

5 The Financial Times, $21^{\text {st }}$ August 1989 
firms to cede $51 \%$ ownership to local partners (GoZ, 2008). But as shown later in the Tawengwa and CBZ cases, these liberatory, locally popular and related policies became a cover for corruption, patronage businesses and politics (Bond and Manyanya, 2002; Compagnon, 2011) leading to the emergence of a wealthy indigenous elite/capitalist class highly intertwined with the ruling party and state as exemplified by land related accumulation in Harare.

The 1990s national crisis manifested in local authorities in the form of collapse of services, flight of qualified workers, liquidity crisis and land scams. The state commissioned Thompson Report (GoZ, 1999) covering the period 1994-1997 unearthed rampant mismanagement by the Mayor Tawengwa led Harare City Council and officials. It reported manipulation of council land sales to benefit elites in and outside council. For instance, in an illegal land deal, the Mayor's company, Solta Pvt (Ltd) was sold a $5278 \mathrm{~m}^{2}$ POS, Stand 10232 Highfield near Gwanzura Stadium for Z\$791 700.00. This was a gross undervaluation when compared to Z\$4.6 million paid by another entity for a similar quality but smaller site of $2030 \mathrm{~m}^{2}$ in the same neighbourhood $^{6}$. Further, an ultra-modern petrol station was constructed on the site without requisite planning permission. Mayor Tawengwa's insider information helped Solta Pvt. (Ltd) to purchase another $2550 \mathrm{~m}^{2}$ prime plot at the corner of Samora Machel Avenue and Enterprise $\operatorname{Road}^{7}$ for Z\$7.1 million on $6^{\text {th }}$ March 1998 (about GBP 236000.00 based on the exchange of around GBP1 $=\mathrm{Z} \$ 30.00$ at the time). Yet, the City Valuation and Estate Management (CVEM) valued the plot at Z\$9.1 million (about GBP303 000.00) ${ }^{8}$.

In addition, the Thompson Report reported that leading retailer OK Bazaars, BP Shell and Mobil Oil were among large corporates that benefited from fraudulent public land sales ${ }^{9}$. For instance, in October 1996, Mobil Oil was sold an Mbare Township plot Stand Number 29630 for Z\$300 000.00 when other objectors to the sale were prepared to pay the market value of $Z \$$ two million $^{10}$. These cases also illustrate how public land sold to elites and corporates was priced lower per unit than when similar land was sold to poor people; citizens' assets were transferred to private entities at below market price depriving Harare City Council of resources to provide citizens with sorely needed services.

By 1996, City of Harare was already in a chronic liquidity crisis with the accounts reflecting net shortfall of Z\$315980 984.0011. The City of Harare was not creditworthy, had no resources for capital projects hence water, road, refuse collection and sewer infrastructure continued to decay to the detriment of citizens as eventually witnessed with the cholera outbreak in 2008/2009 (UNHABITAT, 2010: 210-211). Theft, pilfering of resources and equipment also became rampant ${ }^{12}$.

In an attempt to stem qualified staff exodus in a tough economic climate where salaries had lost value, since the 1990s, Harare City Council has sold commercial and housing land at concessionary prices to staff ${ }^{13}$. But the policy has been deeply abused in recent years as

6 See Annexure B, section 3.3., GoZ (1999)

7 See section 3.4 Report on 'Disposal of council land', GoZ (1999)

8 Unless stated, rates in this paper are based on actual UK and Zimbabwe bank to bank transactions done by the author at the relevant times. By December 1998, the rate was GBP 1 $\geq \mathrm{Z} \$ 60.00$

9 See Annexure 3.4. Stand 10218 Machipisa Shopping Centre and Annexure C (as from 1997).

10 See Annexure P, section 3.17, GoZ (1999)

11 See section 9, of Report on 'The causes of the liquidity crisis in the council', GoZ (1999).

12 See Annexure A, of 'Report on the Fire Brigade and Ambulance Services', Goz, (1999).

13 See Annexure K and L of Report on 'Disposal of council land', GoZ (1999). 
discussed later. Compounding the city's woes was a political crisis. In 1999, the Minister fired Mayor Tawengwa and the council, replacing them with a state appointed Commission led by Elijah Chanakira. That Mayor Tawenga and his council were from the national ruling party and not the opposition underlines the need for a nuanced and plural historiographical understanding of Zimbabwe's fractured and complex society and the diverse actions of polycentric actors. However, instead of facilitating the holding of elections within six months as required by law, the Commission's tenure was renewed repeatedly. From 1999 to the elections in 2008, Harare City was run by illegal commissions notably the Makwavarara and Mahachi Commissions under whose tenure illegal land deals became rampant (City of Harare, 2010: 51-52). The ruling party through state appointed Commissions deepened co-option and corruption of local government: hence the state and not locally elected leaders was in control and presided over the grotesque cases of AbD reported in the Dumba Report (2010).

Thus in the 1990s, pricing, insider information, legal and planning mechanisms in the context of a neoliberal economy and indigenisation policies were used/abused to benefit well connected individuals, emerging indigenous firms as well as traditional settler linked corporations (e.g. OK, BP Shell, Mobil Oil) through privatisation of public land. Solutions to prevailing challenges generated new problems for the many and opportunities for a few. Clearly, seen as corruption, similar processes have been observed elsewhere not only in Africa (Southall, 2005; Goodfellow; 2013; Gillespie, 2013) but in England as well (see Hosken, 2006) ${ }^{14}$. However, the Zimbabwe case is much more than the behaviour of corrupt officials and councillors. It is a comprehensive, systematic state-led attempt at economic restructuring to build and protect indigenous capitalist agents. The uneven results of dispossession are not dissimilar to those of previous settler colonial projects or capitalism everywhere.

\section{Millenium Crisis: Jambanja, 'Money Burning', and Expanded Land Grabs}

Triggered by jambanja, the new millennium was a period of acute crises during which people and institutions survived through 'ngoda' and 'kukorokoza' (illegal gold panning), 'kujingirisa' or ' $k u$ kiya kiya' (improvising and making do) (see Jones, 2010), 'zvibanzi, (deals, and corruption), 'cross-border trading and migration' and 'money burning' creating a 'casino economy' (Gono, 2008: 80-81). Operating 'above' and 'beyond' Mugabe became the norm i.e. finding formal and informal ways of earning income in ways that the state could neither identify nor control. For institutions, this included externalising both operations and locally generated incomes. At the peak of the crisis in 2006-2009, the economy had shrunk by 50\%, hyperinflation had made the Zimbabwe dollar worthless and households survived on diaspora and food donations. The state responded to spiralling civil and political dissent with unprecedented yet inefficacious violence and military style operations; for example the 2005 Operation Murambatsvina (clean up the filth) (UN-HABITAT, 2005), the price control blitz against hoarding and profiteering in 2007 (Operation Dzikisa Mutengo), Operation Chikorokoza Chapera in 2007 (against illegal mining) and following disputed elections in mid-2008, Operation Makavhotera Papi (where did you place your vote).

The hyperinflation era leading to economic implosion in 2008 needs more elaboration from the view of the then Reserve Bank of Zimbabwe (RBZ) governor Dr Gideon Gono. Although Scarnecchia, et al. (2009) urged that Gono's views be disregarded, his insider view has empirical elements that are relevant to this discussion. Citing examples from the Zimbabwe Stock Exchange, Gono's (2008) argument was that while neo-liberal opponents of Zimbabwe's

14 See also "Donnygate" http://www.theguardian.com/society/1999/aug/08/1 [last visited 2nd January 2016] 
government popularised the point that the main cause of hyperinflation and monetary problems were quasi-fiscal activities of the RBZ, the real culprits were shadowy money printing activities by greedy individuals, banks, speculative companies, foreign exchange traders and local stock broking institutions backed by international regime change agents.

According to Gono, Banks and other institutions were printing cheques for fraudulent stock exchange trading and parallel market foreign exchange deals creating a casino capitalism. Shares on the stock exchange increased in value to the tune of millions and trillions in hours and institutions would draw money against these shares. Yet that represented artificial wealth not real value from production in industry. As a result, these scams led to hexillions of dollars in currency circulating in the economy. The scam was bust on 18th November 2008 when Z\$60 hexillion was intercepted at one bank (Gono, 2008) and ended when the de facto use of forex was formalised at the end of 2008. As elaborated later, this fictitious money was used in local authority barter deals completing the link between crisis, finance and privatisation of public land.

At the peak of the post 2000 crisis, the unelected state appointed Commission running Harare hatched a Turnaround Strategy that restructured the council to create directorates. We saw that even as far back as 1996, City of Harare was struggling to pay its workers, to provide services and implement capital projects. The liquidity crisis and hyperinflation made it unfeasible to operate cash transactions. Households and entities had either to operate a 'barter system' or do business using foreign currencies (which was illegal until end of 2008). To finance the turnaround plan and to pay salaries, the Commission and executives of Council initiated barter schemes of land for services, equipment or cash in which the Directorate of Urban Planning Services was critical.

A Directorate of Urban Planning Services (DUPS) was carved out from the Department of Works. Headed by the former City Planner, its key departments were City Planning and Development (CPD), Land Survey, City Architect, Traffic and Transportation, CVEM, City Technical Engineering Services. The Dumba Report (City of Harare, 2010: 39) alleges that the Commissioners, personnel appointed to key positions in this directorate as well as in City Finance and in Housing and Community Services were either close associates and relatives of Minister Chombo or were unprofessional, easy to intimidate and manipulate (NewZimbabwe.com, 2016). What is clear however is that procedures in the valuation, lease and sale of council land were modified/manipulated/subverted for private gain.

To the operations of the already compromised CVEM was added a parallel structure of land identification and processing for sale under the CPD. It is this parallel system that appears to have been used as an instrument in the fraudulent sale of council land. It seems the template of how this could be done as witnessed in the 1990s Tawengwa mayorship was now perfected, expanded and speeded up. As documented in the key reports (GoZ, 1999; City of Harare, 2010) public land was sold without following legal provisions (such as advertising, tender or approval from the Minister where applicable). Furthermore, land was sold fraudulently at give-away prices to favoured beneficiaries with the apparent involvement of the Minister. These quasi or extra-economic means of public land sales (Figure 4) were a public wealth transfer to private ownership that deprived citizens of much needed cash for public services. Focusing on finance mechanisms of dispossession (the credit system, credit debt etc.), Harvey has elaborated this point that contemporary accumulation by dispossession has largely non-physical forms ${ }^{15}$;

15 David Harvey, Marx's Capital, Lecture 12, Chapter 26 - 33; final thoughts on accumulation by dispossession. davidharvey.org [last visited 26 May 2016). 
through pricing where the poor pay more than the rich, credit and unfavourable debt arrangements, resources are transferred from majority poor citizens to private businesses. Contemporary literature on land grabbing appears not to explore these subtle invisible forms of dispossession. In contrast, earlier political economy writings on Zimbabwe (e.g. Arrighi, 1967) underlined how the tax system, pricing of peasant produce and wages of urban workers were designed so as to transfer wealth from indigenous Blacks to settler Europeans and were key grievances in the peasant anti-ploritirianisation struggles in the $1890 \mathrm{~s}$ and early $1900 \mathrm{~s}$.

\section{Commercial Bank of Zimbabwe Banks 'The People's Market'}

The Dumba Report catalogues a series of land allocations to an array of briefcase and shelf companies, what McGregor (2013: 793) termed 'disreputable companies'. But detailed attention was not and has not been given to 'reputable companies' such as the Commercial Bank of Zimbabwe (CBZ) the biggest local bank in the country but mentioned only in passing in the report. On $1^{\text {st }}$ October 2007 City of Harare and CBZ signed a memorandum of agreement for the of sale to CBZ of the People's Market site ${ }^{16}$, a prime POS $15,000 \mathrm{~m}^{2}$ piece of land located south of Greenwood Park at the corner of Seventh Street and Hebert Chitepo (Figure 2 and Figure 3) that for years had operated as a market space for traders selling crafts and vegetables.

The purchase price was $Z \$ 113000000000.00$ (one hundred and thirteen billion dollars). If one were to apply the exchange rate prevailing on the parallel/illegal market that many were using at the time, [GBP1 (one pound) equivalent to Z\$6 500000.00 (six and half million)], the purchase price was no more than twenty thousand pound sterling (GBP20,000.00). City records show that a decade earlier, Council had sold $3000 \mathrm{~m}^{2}$ residential plots in the low density area of Mt. Pleasant for around GBP8,000.00 (eight thousand pound sterling equivalent) and as noted earlier, half a mile to the south, a $2550 \mathrm{~m}^{2}$ plot had been sold to Solta Pvt. Ltd for about GBP 236 000.00 in 1998 (GoZ, 1999). Thus if the People's Market site had been sold in 1998, the price would have been equivalent to at least GBP1.3 million and with appreciation, much more a decade later. The People's Market site is a prime city centre location and would fetch much higher as a commercial plot.

However, the deal was not a financial transaction but a barter exchange: land in exchange for new vehicles, namely ${ }^{17}$ :

- Thirty (30) B1800 Mazda trucks

- Two (2) Mazda D/CAB -Eagles 4X4 and

- One (1) Toyota Hilux 3.0L Diesel 4X4 D/CAB Raider.

At face value, it seems the council was getting a reasonable deal in the hyperinflationary context of Zimbabwe at the time. The CBZ deal illustrates what Gono (2008: 74) described as features of Zimbabwe's casino economy whereby banks were involved in creating artificial money and then releasing it into the economy for foreign exchange trading and non -core business such as 'speculative investments in real estate stocks and other non-core movable assets such as cars and building materials'. Gono's (2008) argument points to the possibility that CBZ used proceeds from 'fictitious capital' or artificial money for purchase of vehicles and then valorised and 'sanitised the loot' through investment in land like The People's Market plot.

But there are further concerns with the deal. Senior council officers claimed that it was the Town Clerk who negotiated the deal's final content ${ }^{18}$. The vehicles appear to be luxury vehicles

${ }^{16}$ File Ref. MSA 15/2007 City of Harare (and Dumba Report for data on the deal cited here)

${ }^{17}$ Page 2, file Ref MSA 15/2007 City of Harare; see also Tendai Mahanchi's (then City of Harare Council Town Clerk) police affidavit, Ref. Borrowdale C.R. 223/03/10. 
for use by executives and not for delivery of key services such as refuse trucks, water pump spares and fire equipment desperately needed at the time. Significantly, laid down legal procedures like (advertisements and change of reservation) were not followed, thus the sale was illegal. Advertisements would have raised objections from the public and other bidders would have offered much more than CBZ. So the deal was to the detriment of City of Harare. Crucially, as at $30^{\text {th }}$ August 2013, the site was zoned POS in the City Centre Local Development Plan 22 (LDP 22), the operative plan approved in 2000. Change of Reservation in terms of section 49 sub sections (2), (3) and (4) of the RTCP Act was not done.

At the end of August 2013, LDP 22 was still displayed on a wall in the reception office, Room 216 Cleveland House, DUPS. The LPD 22 still reflected the 'People's Market' site as a POS not a commercial plot. If change of reservation had been approved, this plan should have been amended accordingly. This was the opinion of the young planners in the office and to the best of their knowledge the site was still POS. Their understanding was in stark contrast to that of a senior planner (with over twenty years experience working in the department) who was adamant that the site was never neither a POS nor council land but private land ${ }^{19}$. He argued that although traders had used it as a market, that did not mean it was public land just as the case at sites like Newlands Shopping Centre where the council has market structures for flower traders, yet the land is not council land.

Yet, all this contradicts what is on the LDP 22 in and the agreement of sale of $1^{\text {st }}$ October 2007. Why would City of Harare sell to CBZ land it did not own?. At CBZ, a projects manager whose team is responsible for such acquisitions claimed that:

The site was always ours ... at least from the time I joined CBZ five years ago.

I remember it as a Luna Park site ... we made it available just before Christmas to about March or just before the Trade Fair... for use as a Luna Park... for entertainment" (Interview, CBZ HQ, afternoon of Thursday $21^{\text {st }}$ August 2014)

Furthermore, CBZ was formed after 1980, when the People's Market was long in existence. As observed by both the Thompson and Dumba Reports, there is confusion, incompetence or corruption at the highest level of the city's urban planning services whichever way one looks at this case. When was change of reservation done if land was POS in 2000, or 1980? If change of reservation was authorised, what were the town planning arguments for it? The city planners prevaricated and would not make all the relevant files available to confirm.

Traders operating at the People's Market were displaced to peri-urban sites, mainly Groombridge and Borrowdale shopping centres and Eastlea/Mutare road opposite VID. The site was fenced, but still empty and under 24 hour private security guard in 2014 . When approached in 2014 the traders were only prepared to volunteer anecdotal information about their dispersal from the People's Market. Their displacement was of the 'revanchist' form (Smith, 1996) where the poor are stigmatised as squatters or illegals and flushed out of spaces like the People's Market targeted for development by the state (or capital in this case) or simply to settle political vendettas. Zimbabwe is well known for such revanchism (see e.g. documents on Operation Murambatsvina; Auret, 1993). People's Market traders lost a more remunerative prime trading site. But crucially and collectively, Harare residents were defrauded not only of their open space but also the financial value.

See you in court: capitalist vs. capitalist and the Borrowdale Nature Reserve

${ }^{18}$ City of Harare key informants in Finance, DUPS and CVEM departments, August 2014.

19 Interview, DUPS, Cleveland House, City of Harare, afternoon of $22^{\text {nd }}$ August 2014. 
Another CBZ barter deal with City of Harare involved Plot 16921 Salisbury Township Lands $(\mathrm{STL})^{20}$. This plot is entangled in change of reservation battles whose history predates the sale to CBZ in 2004. The plot and adjacent plots 16686 STL and 15127 STL are all reserved as POS and Recreational Land, currently used as a Nature Reserve where small wildlife like antelopes and zebra are kept. Central African Building Society (CABS) and Delta Corporation Ltd. offices are neighbours to these plots. Delta Corporation held the lease for plot 16921 STL until it was not renewed by Harare City Council when it expired recently (after 2010).

Around May 1992, Hunyani Holdings Ltd, whose then Chief Executive Officer was Mr Xavier Khadhani and represented by town planning consultant firm Plan Inc. Zimbabwe Ltd. made an unsuccessful application for change of reservation from POS to special office use for all three plots (Plan Inc. Zimbabwe, 1992). Then in the late 1990s an indigenous firm Kama Construction whose chairman was a City of Harare councillor for Mt. Pleasant, applied for all three plots with the intention to develop commercial offices ${ }^{21}$. This was a 'brazen' move by a relatively small-sized indigenous company intending to use the neo-liberal context to venture into the heart of Harare's posh sub-urban office parks. In violation of planning law and procedure $^{22}$, Kama Construction (instead of Harare City Council the land owner) applied to the Minister of Local Government for change of reservation for all three plots from POS to office space. But when residents and neighbouring corporates (including CABS, Trustees of Astra Pension Fund, Astra Holdings Ltd. and Aon Minet Pvt. Ltd.) objected to the change of reservation, The Minister set up an Advisory Board in terms of the RTCP Act Section 9 (4). In 1999, this Advisory Board recommended that stand 16921 be released for office use but the other two remain POS. On this basis, in 2000, the Minister of Local Government authorised a change of reservation for plot $16921^{23}$.

However, the Minister's authorisation was contested by the neighbouring stakeholders and subsequently set aside by the High Court in early August $2002^{24}$ for lack of transparency by City of Harare, for procedural irregularities and failure to follow statutory requirements as per the RTCP Act 1996 [CAP 29: 12). Rhodesian era corporates used law, institutional knowledge to block an aspiring indigenous firm. It seems as if Kama Construction became insolvent and did not pursue the matter with council after this point. Subsequently, in the context of Harare's post 2000 turn-around strategy, City of Harare sold the plot to CBZ in 2004 with claims that City of Harare got vehicles and cash to pay salaries. No records to confirm this were made available. Clearly, the sale was done without a change of reservation as required by law. CBZ claims it only got aware of this requirement when it took plant to the site to initiate development and the neighbours objected. However, it boggles the mind why DUPS facilitated the sale of this public land to CBZ for office use in the absence of a change of reservation? And was the price competitive? To regularise the situation, City of Harare initiated a new application for change of reservation around 2008/2009 ${ }^{25}$. A change of reservation notice in terms of RTCP Act section 49 (4) was placed in the Herald newspaper on Tuesday $10^{\text {th }}$ April 2010. The matter snaked through the process again before landing in the High Court ${ }^{26}$, with Delta Corporation Ltd and CABS as the main objectors and appellants represented by Messrs Scanlen and Holderness, Solicitors,

20 Each STL plot has a corresponding government and local authority file with same title from where data were extracted.

${ }^{21}$ City of Harare and DPP file records for Stand 16921 STL.

22 See High Court Judgement Reference HC 11154/2000

23 File Ref: PD/ER/Stand 16921 STL, City of Harare (Cleveland House).

${ }^{24}$ High Court Judgement Reference HC 11154/2000 and HH132- 02.

25 Ref: PD/WR/Stand 16921 STL, City of Harare, (Cleveland House)

${ }^{26}$ Ref TC/KE/42/CMN/pc/56 City of Harare, Town Clerk 
Harare. As at $30^{\text {th }}$ August 2014, visits to the Administrative Court indicated that judgement was still reserved.

While CBZ is caught up in the tangle some features of the case are pertinent. On file, there is overwhelming support for this change of reservation from both City of Harare councillors and officials on one hand and central government planners who advise the Minister on the other. During interviews, central government planners exuded a determination to get the authority for change of reservation approved and saw the appellants as spoilers. A senior planner remarked "... on this one, CBZ is fine... CABS and Delta are just a nuisance... we will get this one"27. If all procedures were properly adhered to and there are no irregularities this time round, it remains to be seen whether the judge will pick any town planning matters on which to set aside the Minister's authorisation.

In contrast to the People's Market case, The Borrowdale CBZ case is fully that of 'subtle' or 'invisible' extraction of wealth from the public to private corporate interests through the mechanism of finance in processes where state supported indigenous capitalists seek to catch up with or displace settler capital. These processes have been missed by the global capital focused literature on land grabbing largely because there is no physical displacement of poor people. Yet the poor citizens are deprived of full financial benefits from sale of public land in Harare.

The role of actors particularly the state's use of economic and extra-economic instruments is key in $\mathrm{AbD}$. In the context of Zimbabwe's de facto one party state the force of the law, the police, army and prisons will be visited upon any entity (be it civil society, media, intellectuals or even sections of the ruling party) considered an obstruction to the state's programmes of accumulation. Violence or the threat of force is an ubiquitous atmosphere. Before the Dumba Report was discussed by full council, it was leaked to the press on 26th March 2010. However, as widely reported in the media (e.g. Zimbabwe Independent, 2010), instead of investing the allegations and evidence therein, the police arrested the journalists, the Mayor and the eight councillors who were members of the special committee. Police claimed the arrests were on the basis of 'criminal defamation charges' instigated by Mr Phillip Chiyangwa. This set in motion a series of acts of intimidation, harassments, arrests and dismissal of the councillors by Minister $\mathrm{Chombo}^{28}$.

Minister Chombo and Mr Chiyangwa also initiated civil suits against all the councillors and the journalists. These actions financially wore down and silenced the defendants. A senior journalist with The Standard Newspaper confirmed that as at 30th September 2014, the civil suits were 'inactive but still open' ${ }^{29}$. They are kept open as a threat. Should any of the journalists or councillors publish or do anything linked to the report, Minister Chombo and Chiyangwa will activate the civil suits. Inexplicably, the police claimed that they could not initiate charges against Minister Chombo or Mr Chiyangwa because nobody had pressed any charges; a claim considered bizarre by most commentators and legal experts (Zimbabwe Independent, 2010).

\section{Discussion and conclusions}

First a word of caution. As noted in the paper's introduction and in a sober review of four recent books on Zimbabwe (Ndlovu-Gatsheni, 2012: 323) the multi-layered nature and multi-

27 Interview $16^{\text {th }}$ August 2014, at Mukwati Building, $4^{\text {th }}$ Street Harare.

${ }^{28}$ See also "Harare councillors arrested on Chiyangwa's orders", The Standard, 9 $9^{\text {th }}$ April 2010. On-line: thestandard.co.zw [last visited 29/09/2014]

${ }^{29}$ Telephone interview from Oxford 
rootedness of causes to the Zimbabwean crises give rise to various unrelenting ideologically coloured and partisan intellectual/academic interpretations: and "... we will continue to live with different regimes of truth". Thus, AbD presented here offers only a window into aspects of the truth, not the whole truth.

Revisiting the conceptual apparatus sketched earlier (Figure 1), it seems the function of AbD by ruling ZANU (PF) aligned entities is (seen from their perspective) part of building an indigenous capitalism; a nationalist capitalist class and institutions that can resist manipulation by international capital. It is indigenisation of an urban economy that was until now in the hands of foreign and settler capitalists. As noted by High Court Judge J. Adam in August $2002^{30}$, in dealing with cases like the change of reservation for Plot 16921, both City of Harare and Central Government tended to support indigenous firms, first Kama Construction and now CBZ against industries and businesses from the Rhodesian era such as Old Mutual and Delta (see also Manheru, 2014). Consequently, as noted by Rossi, 2012) rather than homogeneity, one has to recognise the presence of competing varieties of capitalism - in present day Zimbabwe; international capital against local capital, state aligned versus non-state capitalists, 'vigilante capitalists' (Bond and Manyanya), briefcase capitalists (City of Harare, 2010); the remnants of 'settler or Rhodesian' era businesses' vs indigenous versions (Manheru, 2014). The variegated nature of capital mirrors that of social forces on the Zimbabwe political terrain and is made more complex by regional, ethnic, historical and racial fissures (Sadomba 2011). Both local and international scholarship on Zimbabwe's crisis and the land question 'mimicks' this political polarity and class struggles.

Zimbabwe's crisis and pariah status since late 1990s had several effects. First it radicalised Robert Mugabe and his ZANU (PF) party, forcing it to resort to liberation war rhetoric and increased use of violence against local opponents. Yet, rather than an 'exhausted nationalist state' (Bond and Manyanya, 2002) economic and land programmes of Zimbabwe's post 2000 ZANU (PF) state make it a radicalised state at the forefront of African self-determination (Moyo and Yeros, 2007); rejuvenated nationalism and economic liberation Sadomba (2011: 6). It may also suggest that a revolution that had lost its way (Astrow, 1983) in an earlier period, is now back on track. According to Harvey $(1985,2003,2014)$, due to capital's inherent contradictions, it experiences periodic crises that are partly and temporarily resolved by switching locations, outlets and other innovations. In Zimbabwe's 1990s neoliberal moment capital switched from manufacturing to speculative financial deals and real estate investments. These trends intensified as the crisis deepened post 1999. Under cover of indigenisation policies, elites and entities like CBZ responded to their crisis of excess money and that of public sector poverty by forging fraudulent alliances with local government to invest in land for security and long term gain.

Furthermore, even with the crises, ZANU (PF) focused on both immediate and long-term survival. The financial crisis and international isolation left urban land as a major resource around which accumulation and elite survival could be pursued with little opposition or interference by the donor community. Donors only woke up to the issue of minerals and resource in rural areas when this seemed to unsettle the global status quo especially relating to diamonds trade. But donors seem oblivious to land grabs taking place right under their noses in Harare probably because these occur without obvious violation of 'human rights' as has been the case in the countryside or that no land belonging to persons of European heritage is affected. Economic rights of urban Zimbabweans have been abused but to date the academic rights discourse seems silent on these.

${ }^{30}$ Page 21 HC 1154/2000 
The crisis had direct links to US and EU regime change agendas and IMF/World Bank neoliberal reforms that triggered massive institutional and household poverty and brought to an end ZANU (PF)'s alliance with big business, multi-lateral and bilateral donors. Meanwhile, 'zvigananda' an elite and comprador class has emerged that is extracting resources at the expense of the majority and in violation of the ideals and dreams of liberation. Equally, ZANU (PF)'s quest to build an nationalistic indigenous capitalist class has parallels with rural bourgeoisie class of Southern Rhodesia that distinguished the country from other colonial economies in Africa (Arrighi, 1976: 36). This leads Sadomba (2011) to suggest that we are due to witness another distinct capitalist economy - African driven this time.

Construction and perpetuation of a sense of crisis (Fairhead et al. 2012: 245) or response to crisis (Hall, 2013: 1585-7) is a central feature of accumulation by dispossession debates. Whether one takes a long term view back to conquest by Cecil John Rhodes's Pioneers and the limits of the subsequent settler economy or the recent neoliberal context of the 1990s and its aftermath, the ZANU (PF) state contributed to the crises as early as the 1980s when it failed to use its position of economic and political advantage to make structural economic changes (Bond and Manyanya, 2002). More recently, where some see political compromise as a quick win solution, the ZANU (PF) state seems to relish perpetuation of the crisis. The military style operations cited earlier create socio-economic and political turbulence that unsettles both ZANU (PF) opponents and supporters, keep society subdued and enhances an environment of crisis where plunder can thrive.

The cases presented in the paper suggest that the ZANU (PF) state and aligned actors have manipulated both neoliberalism and the crisis to expand and enrich a capitalist class that international capital will not be able to dislodge but engage with on its own terms.

Accumulation of capital in urban land has also been achieved through a subtle and cynical policy that abolished rural private property rights while defending those in urban areas. This has enabled resources plundered from the countryside and during the era of the casino economy (Gono, 2008) to be switched to, invested in and reap 'humongous' benefits from urban land speculation. Both $\mathrm{CBZ}$ cases presented here show that AbD as the extraction of wealth may or may not be accompanied physical expulsion of citizens. The paper points to invisible transfers of wealth from the public domain to private corporate interests that has to be understood within the specificities of each context.

Considered in relation to the Thompson and Dumba Reports, The People's Market, and the Plot 16921 (CBZ Borrowdale) cases illustrate that within the current legal system, the indigenisation policy can only proceed with speed if the law is abused/subverted. Nonetheless, only large colonial era corporates like CABS and Delta Corporation have the financial muscle to sustain legal appeals that the rest of citizens in Harare do not have. With donors not taking urban land as a priority, with the best lawyers overworked and with activists exhausted, dead or hounded out of the country, the terrain is left open for unhindered urban public land grabbing.

Since 2000, the ideas of socialism have been replaced by the rhetoric of 'empowerment', indigenisation', sovereignty' and pan Africanism to justify some of the urban land grabs reported in this paper. This suggests that each and every capitalist variant or epoch propagates corresponding narrative/ideas to justify its accumulation (Harvey, 1985). But whether these urban public land grabs are the 'revolution' that Moyo and Yeros (2005) or Sadomba (2011) had in mind when describing Zimbabwe's first millennium decade is contested especially by many in the western world. 
The cases in this paper also illustrate points regarding the "means of accumulation by dispossession' (see Figure 1), the boundaries between economic and extra economic means (Hall, 2013: 1583) and the central role of the state as a key agent/actor. Figure 4 is a summary of the common extra-economic means observed in the irregular sale of public land in Harare since the 1990s. In capital terms, the national crisis was partly about diminished value creation in production; from productive use of abundant labour leading to a switch of capital flows towards speculative financial deals and real estate. Post 2000, global restrictions on local elites made land more attractive as moving currency around became difficult. The plots of public land 'purchased' by CBZ in 2004 and 2007 presented in this paper were still virgin land in 2014. These purchases were long term investments where benefits arise from appreciating land values. CBZ got the land cheap with neither advertisements nor tender. If tenders had been done, it is highly likely that the Rhodesian era corporates, CABS and Old Mutual (the largest property developers) and Delta would have given CBZ a good run for their money. Delta held a lease on the Borrowdale plot at the time (2004) CBZ claimed to have bought the land from City of Harare .

Questions on the fate and status of MDC type of political opposition also emerge. In her work on surveillance and the city, McGregor (2013: 784 - 85) highlights reports of corruption by MDC led local councils and the impact such corruption had in eroding support for the MDC on the eve of the 2013 elections. But the foundational linkages with the land issue remain unexplored. McGregor's (2013) work points to a wider array of political actors beyond ZANU (PF) involved in urban land grabbing; mainly against but also as participants in grabbing. Although beyond the scope of this paper, there clearly is need to research the inter and intra party rivalry and politics associated with urban public land grabbing, including connections to the ruling party's imperative of total political power (Compagnon, 2011)..

Given Thompson Report (GoZ, 1999) and Dumba Report (2010), the cases presented in this paper could be just a tip of the iceberg. However, they indicate, that cumulatively, what appear to be small-scale urban land grabs have significant spatial coverage, economic and political impacts. That they take place in prime central city areas suggests that significant processes of wealth accumulation are unfolding - with wealth fraudulently transferred from the many to the few. This flagrant subversion of institutions and public property violates Section 308 (1-4) of the Zimbabwe constitution (GoZ, 2013: 120) that seeks to protect public funds and property from loss, destruction, misapplication and misuse. The urban land grab cases also reveal how lately urban planning in Zimbabwe has become a thoroughly compromised and abused profession. Whether at some point in future Zimbabweans will demand 'punishment for persons responsible' and 'recovery of the misappropriated funds and property' as provided for in the constitution remains to be seen. For now there seems to be no agitation for it.

A further research question relates to how those affected by processes of urban land grabbing (Figure 1) respond. In particular, is the issue of why Zimbabwean citizens appear not to engage in sustained grassroots resistance (Edelman, 2013 et. al) and land wars to resist fraudulent and forcible state transfer of land from public to private hands as witnessed in India (Levien, 2012), in Turkey (The Guardian, 2014) and Latin America or Kenya ${ }^{31}$. For years, the Combined Harare Residents Association used the legal route to expose and fight for a people oriented local governance in Harare. More recently some MDC councillors (Dumba Report), the Wetlands Survival Forum Trust and the media have sought to expose cases of land grabbing. However it

31 Operation Firimbi, Blow The Whistle Against Land Grabbing, http://www.mazinst.org/mazpub/initiative/ofirimbi [last visited 30th September 2014] 
seems to be a losing battle and certainly there is no rising public agitation against urban land grabbing, why? The legendary capacity of the Zimbabwean state to unleash unprecedented wholesale and targeted violence on citizens as witnessed during Gukurahundi (CCJP, 1997), Murambatsvina 2005 (UN-HABITAT, 2005) and at election times, most recently the 2008 elections is a key answer to this. The 'harvest of fear' emerging from memories of these episodes (has its roots in the liberation struggle (Sadomba, 2011) and the Rhodesian state it fought against) keeps citizens subdued.

But there could be more than the harvest of fear to explain grassroots 'inaction' since violence alone is never an adequate explanation. ZANU (PF) has been astute at enrolling large sections of the rural and urban populations to also partake in processes of AbD. With jambanja, urban and peri-urban areas have been informalized enabling party supporters access to spaces for housing, trading and urban agriculture. In the peri-urban areas in particular, rural land with no individual rights is 'grabbed' for urban uses providing key actors with immediate and long term streams of rental income; reinforcing the earlier assertion that cases in this paper could be the tip of broader $\mathrm{AbD}$ by a variety of polycentric actors. In a context where the police and judiciary are highly co-opted into ZANU (PF), a mood that "to fight the ruling elites does not pay but collaboration reaps rewards" has been cultivated. Even political opposition activists seem to have been compromised into this mentality and practices (McGregor, 2013). Those who fight capitalism or ZANU (PF) seem to emerge with characteristics of the forces they had opposed just as ZANU (PF) has mirrored the template of settler Rhodesians that it replaced. Moreover, there is an 'exit valve' for those unable to withstand the pressure or do not want to be co-opted; viz crossing borders seeking alternative survival (Mbiba, 2005). Ironically, the middles classes produced by ZANU (PF)'s 1980s education system and best placed to resist accumulation by dispossession are the most attracted to it or first to cross borders into the diaspora. Those who stay are viewed as failures with no options elsewhere. A grassroots uprising against urban public land grabbing is highly unlikely in the near future... Accumulation Continua! 


\section{References}

Adams, William M. and Megaw, Charles C. (1997) Researchers and the rural poor: asking questions in the Third World. Journal of Geography in Higher Education 2.2, 215 - 229.

Arrighi, Giovanni (1967)The political economy of Rhodesia. Mouton, The Hague.

Arrighi, Giovanni, Aschoff, Nicole and Scully, Ben (2010) Accumulation by dispossession and its limits in the Southern Africa Paradigm revisited. Studies in Comparative International Development 45, 410-438

Astrow, Andre (1983) Zimbabwe: a revolution that lost its way. Zed Press, London.

Auret, Michael (1993) Churu farm: a chronicle of despair. Catholic Commission for Justice and Peace, Harare.

Baglioni, Elena and Gibbon, Peter (2013) Land grabbing, large- and small-scale farming: what can evidence and policy from the $20^{\text {th }}$ century Africa contribute to the debate. Third World Quarterly 4.9, 1558 - 1581.

Becker, Laurence, C. (2013) Land sales and the transformation of social relations and landscape in peri-urban Mali. Geoforum 46, 113 -123.

Bond, Patrick and Manyanya, Masimba (2002) Zimbabwe's plunge: exhausted nationalism, neoliberalism and the search for social justice. London: The Merlin Press

Borras Jr Saturnino M. and Franco, Jennifer C. (2012) Global land grabbing and political reactions 'from below'. Third World Quarterly 34.9, 1723-1747.

Borras Jr Saturnino M. and Franco, Jennifer C. (2013) Global land grabbing and trajectories of agrarian change: a preliminary analysis. Journal of Agrarian Change 12.1, 4-9.

CCJP (1997) Gukurahundi in Zimbabwe: A Report on The Disturbances in Matabeleland and the Midlands, 1980-1988. Hurst and Company, London.

CDR (2002) Zimbabwe crisis: an issue paper from the Centre for Development Research, Copenhagen. Centre for Development Research (CDR), Copenhagen.

Cheater, Angela P. (1984) Idioms of accumulation: rural development and class formation among freeholders in Zimbabwe. Mambo Press (Zambeziana), Gweru.

City of Harare (2010) Special Investigations Committee's Report on City of Harare's Land Sales, Leases and exchanges From the Period October 2004 to December 2009, 23 March 2010 (Dumba Report). City Of Harare Report of the Special Investigation Committee, Chaired by Councillor Warship Dumba, then Councillor for Ward 17, Mt. Pleasant, Harare.

Compagnon, David (2011) A predictable tragedy: Robert Mugabe and the collapse of Zimbabwe. Philadelphia, PA: University of Philadelphia Press.

Crisis Coalition Zimbabwe (2003a) Sovereignty through democracy: the Commonwealth and Zimbabwe's multi-layered crisis. Crisis Coalition Zimbabwe, Harare.

Crisis Coalition Zimbabwe (2003b) Mastering patience... or mastered by apathy? An update on the Zimbabwe situation. Crisis Coalition Zimbabwe, Harare.

Edelman, Marc., Oya Carlson and Borras Jr Saturnino M. (2013) Global land grabs: historical processes, theoretical and methodological implications and current trajectories. Third World Quarterly 34.9, 1517-153.

Fairhead, James., Leach Melissa and Scoones, Ian (2012) Green grabbing: a new appropriation of nature? The Journal of Peasant Studies 39.2, 237-21.

Freeth, Ben (2011) Mugabe and the White African. Lion Hudson plc, Oxford.

Gillespie, Thomas, A. (2013) Accumulation by urban dispossession: struggles over urban space in Accra, Ghana. PhD Thesis, School of Geography, The University of Leeds.

Glassman, Jim (2006) Primitive accumulation, accumulation by dispossession, accumulation by 'extra-economic' means. Progress in Human geography 30.5, 608-625.

Godwin, Peter (2011) The fear: Robert Mugabe and the martyrdom of Zimbabwe. Little, Brown and Company, London. 
Gono, Gideon (2008) Zimbabwe's casino economy: extraordinary measures for extraordinary challenges. ZPH Publishers Pvt. Ltd, Harare.

Goodfellow, Tom (2013) Planning and development regulation amid rapid growth: explaining divergent trajectories in Africa. Geoforum 48, 83-93.

GoZ (1993) Preference for indigenous contractors: Treasury Circular No. 2 of 1993 to all Heads of Ministries and Parastatals. Government of Zimbabwe, Ministry of Finance, Causeway, Harare, $15^{\text {th }}$ March 1993. Ref: B/75/169.

GoZ (1994) Regional Town and Country Planning (Use Groups) Regulations, Statutory Instrument 216 of 1994, 30th September 1994. Government Printer, Harare.

GoZ (1996a) Regional, Town and Country Planning Act, [Chapter 29: 12) Revised edition. Government Printer, Harare.

GoZ (1996b) Urban Councils Act [Chapter 29: 15] Revised edition. Harare: Government Printer

GoZ (1999) Report of the Investigating Team Into The State of Governance and General Administration of The City of Harare" of $28^{\text {th }}$ May 1999, set up by Hon. J.L. Nkomo, MP, then Minster of Local Government and National Housing and chaired by Mr M.J.

Thompson. Government of Zimbabwe [Restricted] (The Thompson Report), Harare.

GoZ (2008) Indigenization and Empowerment Act, March 7, 2008. Government Printer, Harare.

GoZ (2013) Zimbabwe: Constitution of Zimbabwe Amendment (No. 20) Act 2013. Government Printer, Harare.

Hall, Derek (2013) Primitive accumulation, accumulation by dispossession and the global land grab. Third World Quarterly 34. 9, 1582-160.

Hanlon, Joseph., Manjengwa, Jeanette and Smart, Theresa (2013) Zimbabwe takes back its land. Kumarian Press, Sterling Virginia.

Harvey, David (1985) The urbanisation of capital: studies in the history and theory of capitalist urbanisation. Basil Blackwell Ltd, Oxford.

Harvey, David (2003) The new imperialism. Oxford University Press, Oxford.

Harvey, David (2012) Rebel Cities: From the Right to the City to the Urban Revolution. London: Verso

Harvey, David (2014) Seventeen contradictions and the end of capitalism. Oxford University Press, Oxford.

Hodkinson, Stuart (2012) The new urban enclosures. City 16.5, 500-518.

Hosken, Andrew (2006) Nothing like a dame: the scandals of Shirley Porter. Granta, London.

ICG (2004) Blood and soil: land politics and conflict prevention in Zimbabwe and South Africa. International Crisis Group Press (ICG), Brussels.

Jones, Jeremy, L. (2010) Nothing is straight in Zimbabwe: the rise of the kukiya kiya economy 2000-2008. Journal of Southern Africa Studies 36.2, 285-299.

Kamete, Amin (2006) The return of the jettisoned: ZANU (PF)'s crack at 're-urbanising' in Harare. Journal of Southern African Studies 32.2, 255-71.

Levien, Michael (2011) Special economic zones and accumulation by dispossession in India. Journal of Agrarian Change 11.4, 454-483.

Levien, Michael (2012) The land question; special economic zones and the political economy of dispossession in India. The Journal of Peasant Studies 39.3-4, 933-969.

MacGregor, JoAnn (2013) Surveillance and the city: patronage, power sharing and the politics of urban control in Zimbabwe. Journal of Southern African Studies 39.4, 783-805.

Mamdani, Mahmood (2008) Lessons of Zimbabwe. London Review of Books 30.23,17-21(4 ${ }^{\text {th }}$ December 2008).

Manheru Nathaniel (2014) Let Rhodesian industries collapse. NewZimbabwe.com, $14^{\text {th }}$ June 2014. http://www.newzimbabwe.com/ [last visited $1^{\text {st }}$ October 2014]

Marongwe, Nelson (2002) The fast track resettlement and urban development nexus: the case of Harare. Zimbabwe Regional Environment Organisation (ZERO), No. 158 Fife Avenue Harare. Paper presented at the Symposium on Delivering Land and Securing Rural 
Livelihoods: Post Independence land Reform and resettlement in Zimbabwe, Mont Clair, Nyanga, 26-28 march 2003.

Marongwe, Nelson, Mukoto, Shame and Chatiza Kudzai (2011) Scoping study: urban land markets in Zimbabwe. South Africa, Urban LandMark.

Marx Karl (1990) Capital, Vol 1. Penguin Classics, London.

Mbiba, Beacon (2005) Zimbabwe's global citizens in 'Harare North': some preliminary observations, in Palmberg M. and Primorac R. (eds.) Skinning the skunk: facing Zimbabwean futures. The Nordic Africa Institute, Uppsala.

Mbiba, Beacon and Ndubiwa, Michael, N. (2009) The role of local government in promoting decent work in construction and related services with special reference to Bulawayo City, in Lawrence J. R. and Verna, E. (eds.) Labour Conditions for Construction: building cities, decent work and the role of local authorities. Wiley-Blackwell, Oxford.

Mbiba, Beacon (2010) Burial at home? Dealing with death in the diaspora and in Harare, in McGregor, J. and Primorac, R (eds.) Zimbabwe's new diaspora: displacement and the cultural politics of survival. Berghahn Books, Oxford.

Moyo, Sam and Yeros, Paris (2005), Land occupations and land reform in Zimbabwe: towards the national democratic revolution', in Moyo, S. and Yeros, P. (eds.) Reclaiming the land: the resurgence of rural movements in Africa, Asia and Latin America. Zed Books, London.

Moyo, Sam and Yeros, Paris (2007) The radicalised state: Zimbabwe's interrupted revolution, Review of African Political Economy 111, 103-121.

Moyo, Sam and Yeros, Paris (2009) Zimbabwe ten years on: results and prospects. Pambazuka News, Issue 419, $12^{\text {th }}$ February 2009. http://www.pambazuka.net/en/category/features/54037 [last visited 10 January 2015]

NewZimbabwe.com (2014) Land row: residents sue 'greedy' Mupfumi. New Zimbabwe.com 17 May 2014. http://www.newzimbabwe.com/new [last visited 30th September 2014]

NewZimbabwe.co. (2016) Chombo and the rot at Harare City Council. NewZimbabwe.com, $30^{\text {th }}$ May 2016. http://www.newzimbabwe.com/new [last visited 6th June 2016]

Ndlovu-Gatsheni, Sabelo, J. (2012) Beyond Mugabe-centric narratives of the Zimbabwe crisis Review Article. African Affairs, 111 (443): 315 0- 323.

Oya, Carlos (2013) The land rush and classic agrarian questions of capital and labour: a systematic scoping review of the socio-economic impact of land grabs in Africa. Third World Quarterly 34.9, 1532-557.

Plan Inc. Zimbabwe (1992) Town Planning Report on Stands 16686 and 16921 Harare Township and Stand 15127 Salisbury Township Lands: Application for Change of Use for Open Space Reservation to Special Office Use: Hunyani Holdings Ltd. Plan Inc. Zimbabwe, Harare.

Rossi, Ugo (2012) On the varying ontologies of capitalism; embeddedness, dispossession, subsumption. Progress in Human Geography 37.3,348-35.

Sadomba, Wilbert Zvakanyorwa (2011) War veterans in Zimbabwe's Revolution: challenging neo-colonialism and settler and international capital. Weaver Press, Harare \& James Currey, Suffolk.

Scarnecchia, Timothy., Alexander, Jocelyn and 33 Others (2009) Reflections on Mahmood

Mamdani's 'Lessons of Zimbabwe', Concerned African Scholars (CAS), Bulletin No. 82,

pages 15-17, Summer 2009. http://concernedafricascholars.org/docs/acasbulletin82.pdf.

Scoones, Ian., Marongwe, Nelson., Mavedzenge, Blasio., Mahenyehenye, Jacob., Murimbarimba, Felix and Sukume, Chrispen (2010) Zimbabwe's land reform: myths and realities. James Currey, Suffolk.

Smith, Neil (1996) The new urban frontier; gentrification and the revanchist city. Routledge, London. 
Springer, Simon (2013) Book Review of Banerjee-Guha (ed.) (2010) Accumulation by dispossession: transformative cities in the new global order. Sage, Thousand Oaks, CA. Urban Studies 50, 445.

Southall, Roger (2005) The Ndugu Report: Land and Graft in Kenya. Review of African Political Economy: Imperialism and African Social Formations 32.103,142-15.

Sylvester, Christine (1990) Simultaneous revolutions: the Zimbabwean case. Journal of Southern African Studies 16.3,452-475.

Sylvester, Christine (1991) Zimbabwe: the terrain of contradictory development. Westview Press, London.

The Guardian (2014) A year after the protests, Gezi Park nurtures the seeds of a new Turkey. The Guardian, London, $29^{\text {th }}$ May 2014. http://www.theguardian.com/world/2014/may/29/[last visited, 30th September 2014$]$

The Standard (2014) Mutare council loses Meikles Park to Mupfumi. The Standard Newspaper, Harare, $4^{\text {th }}$ May 2014, http://www.thestandard.co.zw/2014/05/04/mutare-council-losesmeikles-park-mupfumi/ [last visited, $30^{\text {th }}$ September 2014]

The World Bank (1989) Zimbabwe: private investment and government policy. The World Bank, Washington DC: Southern Africa Department.

The World Bank (2011) Rising global interest in farmland: can it yield sustainable and equitable benefits? The World Bank, Washington DC.

UN-HABITAT (2005) Report of the Fact-Finding Mission to Zimbabwe to assess the Scope and Impact of Operation Murambatsvina by the UN Special Envoy on Human Settlements Issues in Zimbabwe, Mrs. Anna Kajumulo Tibaijuka. UN-HABITAT, Nairobi.

UN-HABITAT (2010) The State of African Cities, 2010. Governance, Inequality and Urban Land Markets. United Nations Human Settlements Programme (UN-HABITAT)/UNEP, Nairobi.

Weiss, Ruth (1994) Zimbabwe and the new elite. British Academic Press, London.

Zimbabwe Independent (2010) Chombo, Chiyangwa Saga: test case of police reform. Zimbabwe Independent, Harare, 15 ${ }^{\text {th }}$ April. On-Line: www.theindependent.co.zW [last visited 29/09/2014] 
Figure 1: Conceptual Apparatus: Sketch of Elements to Understanding Accumulation by Dispossession

\begin{tabular}{|c|c|c|}
\hline & Primitive Accumulation for Marx (PA) & $\begin{array}{l}\text { Accumulation by Dispossession for David } \\
\text { Harvey }(\mathrm{AbD})\end{array}$ \\
\hline $\begin{array}{l}\text { Function for } \\
\text { capitalism }\end{array}$ & $\begin{array}{l}\text { - To create the preconditions for } \\
\text { capitalism; before capitalism matures } \\
\text { (pre-history of capitalism) }\end{array}$ & $\begin{array}{l}\text { - To enable capitalist expansion \& } \\
\text { speed up } \\
\text { - To enable capital to deal with crises } \\
\text { arising from the many inherent } \\
\text { contradictions (at least seventeen) } \\
\text { [Harvey, 2014] }\end{array}$ \\
\hline $\begin{array}{l}\text { Means specific } \\
\text { to it (to PA or } \\
A b D \text { ) }\end{array}$ & $\begin{array}{l}\text { - Economic means - the silent } \\
\text { compulsion of economic relations } \\
\text { - Extra-economic means - conquest, } \\
\text { robbery, murder, violence, state driven } \\
\text { force and expropriation. } \\
\text { - Privatisation, financialisation } \\
\text { Critical role the state }\end{array}$ & $\begin{array}{l}\text { Similar to those in PA (to the left) but: } \\
\text { - taking place much faster, more subtle, } \\
\text { - more devastating } \\
\text { Privatisation, financialization; } \\
\text { construction and perpetuation of 'sense' } \\
\text { of crises; changing role of the state. [see } \\
\text { also Fairhead et al. 2012] }\end{array}$ \\
\hline $\begin{array}{l}\text { Outcomes of } \\
\text { process }\end{array}$ & $\begin{array}{l}\text { Two main outcomes } \\
\text { - Social means of production are } \\
\text { tumed to capital; land is tumed into } \\
\text { capital } \\
\text { - Producers tumed into wage } \\
\text { labourers; two classes emerge - the } \\
\text { capitalists and the proletariat. } \\
\text { - Injustices, poverty, wars, } \\
\text { environmental degradation lead on } \\
\text { from this. }\end{array}$ & $\begin{array}{l}\text { The production and reproduction of same } \\
\text { outcomes as in PA; } \\
\text { But diverse contexts beyond the agrarian } \\
\text { (farm) and production (factory) contexts } \\
\text { - Including commodification, privatisation, } \\
\text { of public, social, cultural spaces and } \\
\text { commodification of private personal } \\
\text { spaces, the mind and body. }\end{array}$ \\
\hline $\begin{array}{l}\text { Actors in the } \\
\text { process - key } \\
\text { drivers }\end{array}$ & $\begin{array}{l}\text { - National, Global Capital } \\
\text { Key role of the state; state } \\
\text { expropriation, use of coercive force } \\
\text { and violence }\end{array}$ & $\begin{array}{l}\text { - Local, National, Global Capital; } \\
\text { conditions of globalisation and variegated } \\
\text { capitalism determine the actors. } \\
\text { - Role of the state as in PA; debt, finance, } \\
\text { regulation }\end{array}$ \\
\hline $\begin{array}{l}\text { Response of } \\
\text { those affected }\end{array}$ & $\begin{array}{l}\text { Responses of: } \\
\text { - Working class } \\
\text { - Colonised peoples } \\
\text { - Slaves } \\
\text { - Peasants }\end{array}$ & $\begin{array}{l}\text { Similar to PA; but different capacities and } \\
\text { tools depending on context. } \\
\text { - Working class } \\
\text { - Peasants } \\
\text { - Disposed classes } \\
\text { - The grassroots [see Borras and } \\
\text { - Franco, 2013] } \\
\end{array}$ \\
\hline
\end{tabular}


Figure 2: The People's Market location in relation to Harare CBD

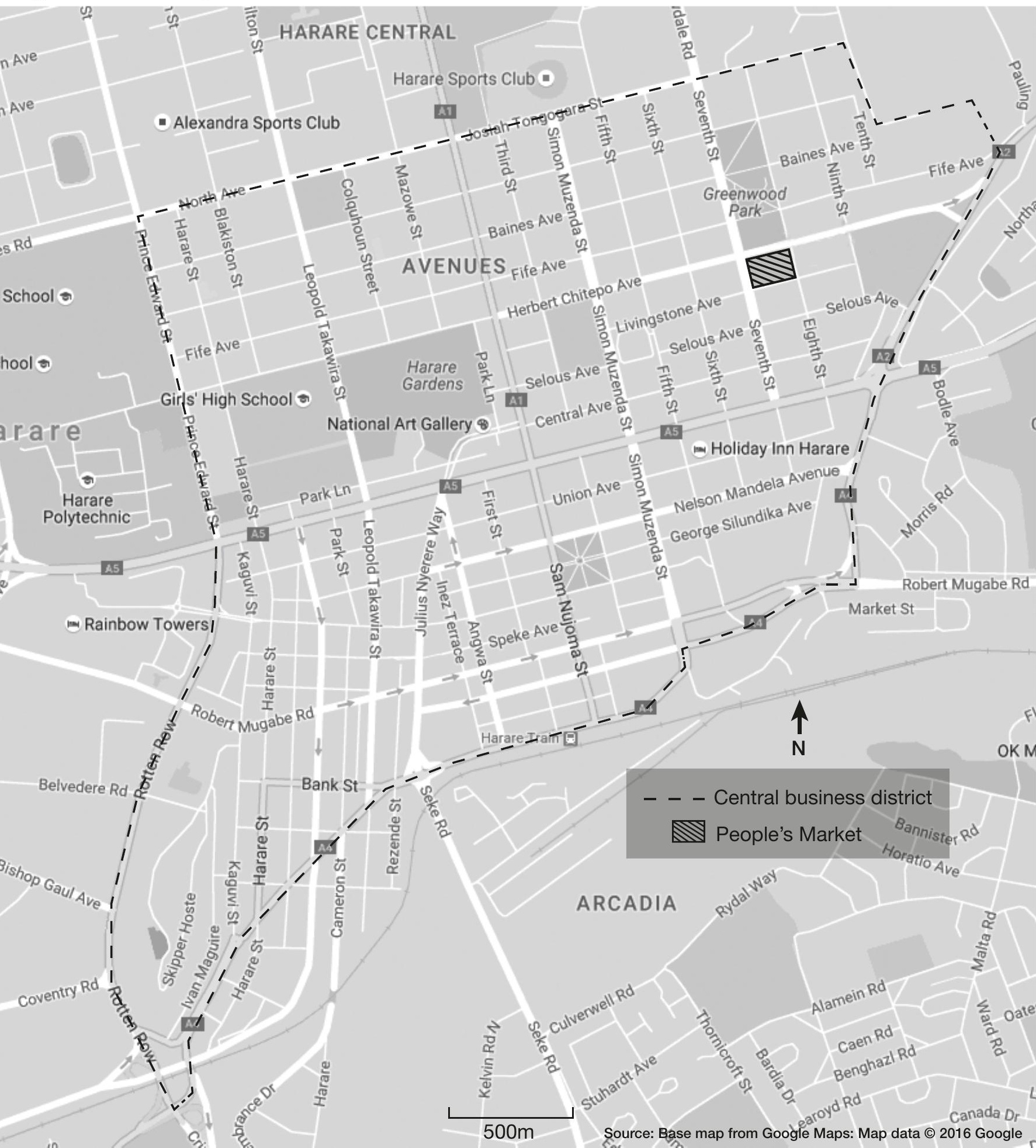


Figure 3: The People's Market: A Public Open Space now 'CBZ Property'

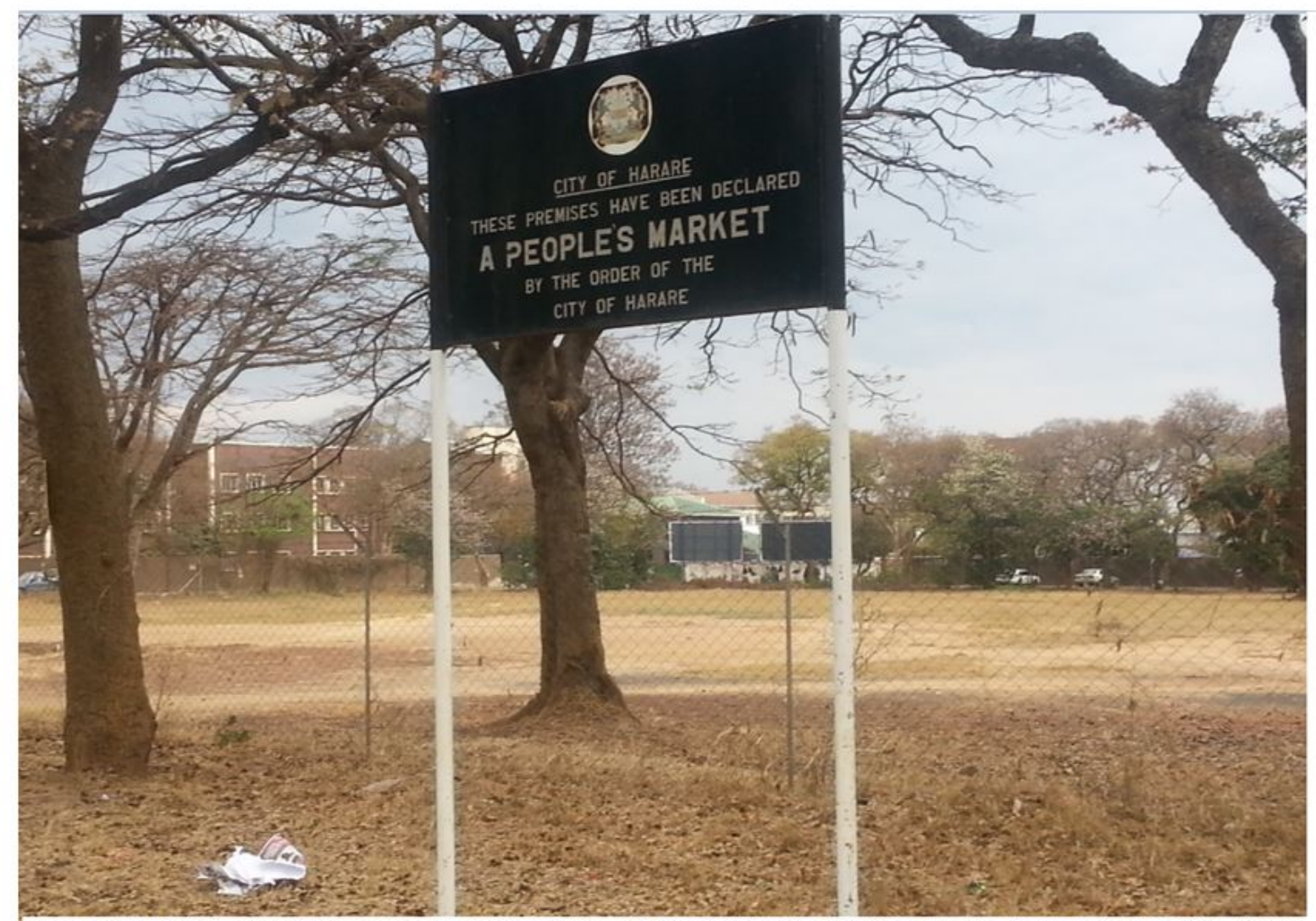

The People's Market, opposite Greenwood Park, Corner Seventh Street and Herbert Chitepo Avenue, North East of the CBD. Sold to CBZ in 2007

(C) Beacon Mbiba, August 2014

N.B. This sign which was still intact on $30^{\text {th }}$ August 2014 had been removed by August 2016. But the fencing and the guards remained. 
Figure 5: Quasi-economic means of capital accumulation in Harare

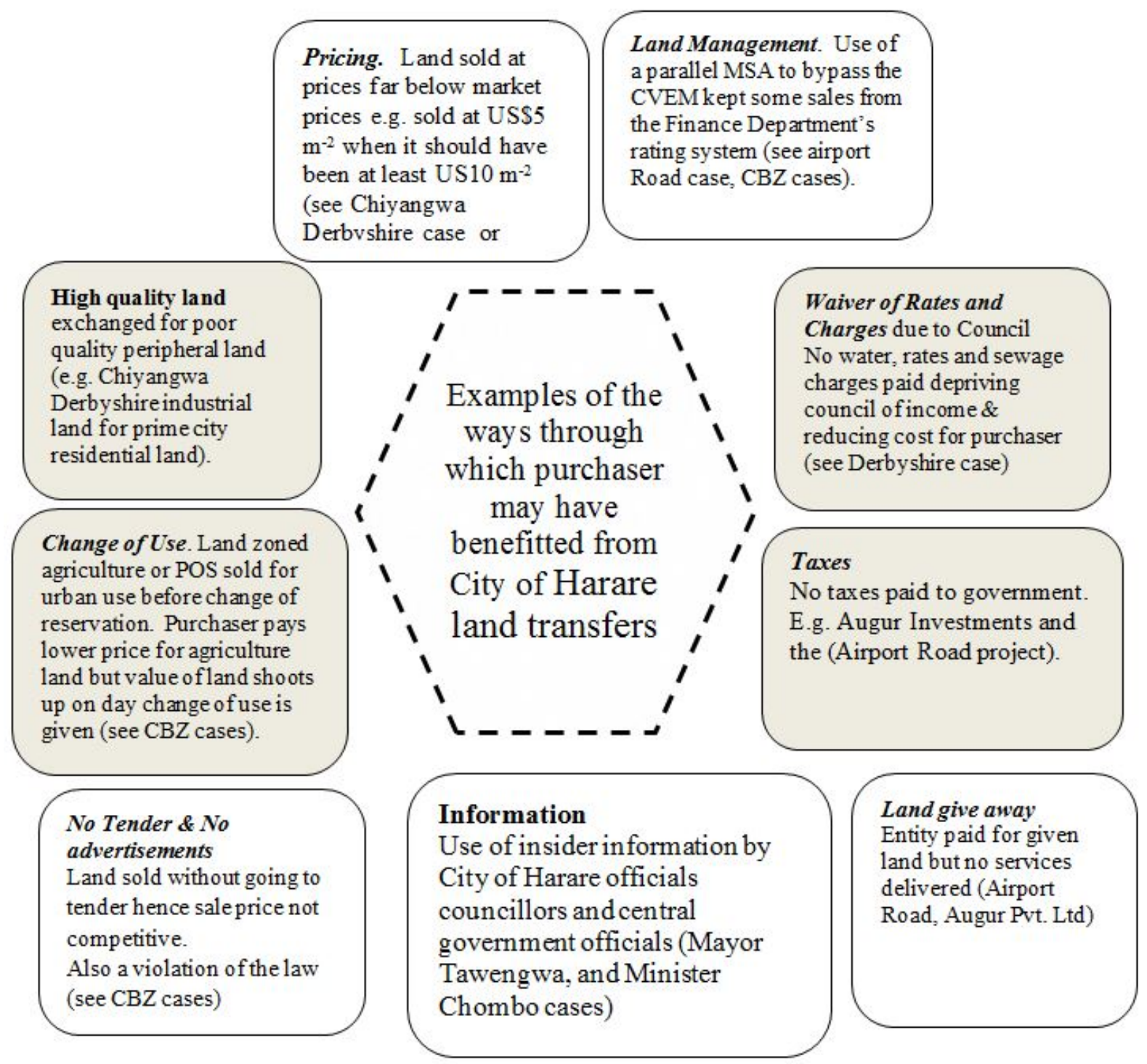

Source: Author Synthesis 
